\title{
Initial shoot development and root architecture of citrus rootstocks
}

\section{Desenvolvimento inicial de parte aérea e arquitetura de raiz de porta-enxertos de citros}

\author{
Maria Aparecida da $\mathrm{Cruz}^{1 *}$; Deived Uilian de Carvalho ${ }^{1}$; Denis Santiago da Costa ${ }^{2}$; \\ Ronan Carlos Colombo ${ }^{3}$; Camilla de Andrade Pacheco ${ }^{4}$; Zuleide Hissano Tazima; \\ Carmen Silvia Vieira Janeiro Neves ${ }^{6}$
}

\begin{abstract}
A well-developed root system is a very important characteristic of rootstocks. Initial plant characterization is a potential technique to highlight cultivars with desirable root architecture for the diversification of rootstocks in the national citriculture. Thus, the aim of this study was to evaluate the initial shoot development and root architecture of citrus cultivars used as rootstocks. Seeds from five rootstocks, 'Cleopatra' mandarin, 'Rangpur' lime, 'Rough' lemon, 'C13' and 'Troyer' citranges, were sown in black polyethylene bags. A completely randomized block design with five replications and one plant per plot was applied. At 30 and 45 days after emergence, shoots and roots were collected for analysis. Shoot analysis measured the total number of leaves, leaf area, stem diameter, plant height, and fresh and dry matter weights. Root analysis evaluated fresh and dry matter weights and root architecture by image analysis, which recorded root traits including primary, secondary, and tertiary root numbers; length and total volume; and the percentage of secondary roots present in the upper third of the primary root. Shoot and root data of fresh and dry weights were submitted to variance analysis and compared using Tukey's test $(5 \%)$. The remaining root data were standardized for variance 1 and studied through principal component analysis. The 'C13' citrange showed good shoot development, with greater leaf area, plant height, stem diameter, and shoot fresh and dry matter weights during both evaluation periods, followed by the 'Troyer' citrange. The 'Cleopatra' mandarin had the smallest shoot and root development during both evaluation periods, presenting lower primary root, secondary root, and root volume than other cultivars evaluated at the same time. The 'Troyer' citrange had fewer roots in the upper third of the primary root and a higher root insertion angle.
\end{abstract}

Key words: Initial plant characterization. Root system. SmartRoot.

\section{Resumo}

Um sistema radicular bem desenvolvido é uma característica muito importante dos porta-enxertos. A caracterização inicial das plantas é uma técnica que apresenta potencial para detecção de cultivares com arquitetura desejável de raízes para uso na diversificação dos porta-enxertos da citricultura nacional. Com isso, o objetivo do estudo foi avaliar o desenvolvimento inicial da parte aérea e a arquitetura de raiz

\footnotetext{
1 Eng $^{\text {os }}$ Agr $^{\text {os }}$, Discentes de Doutorado em Agronomia, Universidade Estadual de Londrina, UEL/CCA, Londrina, PR, Brasil. E-mail: mary_ac18@hotmail.com; deived10@gmail.com

2 Eng ${ }^{\circ}$ Agr $^{\circ}$, Prof. Dr., Instituto Federal de Mato Grosso do Sul, IFMS, Nova Andradina, MS, Brasil. E-mail: denisccauel@gmail.com

3 Eng $^{\circ} \mathrm{Agr}^{\circ}$, Dr. em Agronomia, UEL/CCA, Londrina, PR, Brasil. E-mail: ronancolombo@yahoo.com.br

4 Eng $^{\mathrm{a}}$ Agr $^{\mathrm{a}}$, Prof ${ }^{\mathrm{a}}$ Dr $^{\mathrm{a}}$, Departamento de Agronomia UEL/CCA, Londrina, PR, Brasil. E-mail: camillaap@uel.br

5 Eng ${ }^{\text {a }}$ gra ${ }^{\mathrm{a}}$, Pesquisadora Dra , Instituto Agronômico do Paraná, IAPAR. Londrina, PR, Brasil. E-mail: zuleide@iapar.br

6 Eng $^{\mathrm{a}}$ Agr $^{\mathrm{a}}$, Prof ${ }^{\mathrm{a}}$ Dra ${ }^{\mathrm{a}}$, Pós-Graduação em Agronomia, UEL/CCA, Londrina, PR, Brasil. E-mail: csvjneve@uel.br

* Author for correspondence
} 
de cinco cultivares de citros usadas como porta-enxertos. Sementes de cinco porta-enxertos, tangerina 'Cleópatra', limão 'Cravo', limão 'Rugoso', citrange 'C13' e 'Troyer', foram semeadas em sacolas pretas de polietileno. Foi utilizado delineamento experimental de blocos inteiramente casualizados, com cinco repetições e uma planta por bloco. Aos 30 e 45 dias após emergência a parte aérea e as raízes foram coletadas para análise. As análises de parte aérea avaliaram número total de folhas, área foliar, diâmetro do caule, altura da planta, massa fresca e seca. Análises de raízes avaliaram massa fresca e seca e arquitetura de raízes por análise de imagem, que avaliou características como, número de raízes primárias, secundários e terciárias, comprimento e volume total de raízes e porcentagem de raízes secundárias presentes no primeiro terço da raiz principal. Os dados de parte aérea e massa fresca e seca de raiz foram submetidos à análise de variância e comparados usando teste de Tukey (5\%). O restante dos dados de raiz foram padronizados para a variância 1 e estudados pela análise de componentes principais. O citrange 'C13' apresentou bom desenvolvimento de parte aérea, com maior área foliar, altura de planta, diâmetro de caule e massa fresca e seca de parte aérea em ambos períodos avaliados, seguido pelo citrange 'Troyer'. A tangerina 'Cleópatra' apresentou menor desenvolvimento radicular e de parte aérea nos dois períodos avaliados, com menor desenvolvimento de raízes primárias, secundárias e menor volume, comparada com as outras cultivares avaliadas no mesmo período. O citrange 'Troyer' apresenta poucas raízes no terço superior e maior ângulo de inserção das raízes.

Palavras-chave: Caracterização inicial de plantas. Sistema radicular. SmartRoot.

\section{Introduction}

Brazilian citrus production is well-known worldwide, with Brazil being the largest orange producer since the 1980s and the fourth largest mandarin producer globally (FAO, 2015). Rootstocks are very important because they influence several aspects of plant development, including plant growth and yield; disease and pest resistance; and adaptation to environmental stresses. They also affect internal fruit quality parameters, such as total soluble solids, acidity levels, and vitamin C content (BENJAMIN et al., 2013; MEDINA et al., 2005).

'Rangpur' lime (Citrus limonia Osbeck) is the most common rootstock in the national citriculture. It has been estimated that this specie represents more than $85 \%$ of the rootstocks used in Brazil owing to its tolerance to water stress, C. tristeza virus resistance, compatibility with most canopy cultivars, and good yield induction (ALMEIDA; PASSOS, 2011; AULER et al., 2014; MOURÃO FILHO et al., 2007). However, the susceptibility of this cultivar to diseases, such as Citrus sudden death associated virus and Phytophthora spp., the need to improve fruit quality, and the risks of new diseases and pest outbreaks that could easily spread over the narrow genetic variability, has stimulated new research to increase the number of suitable cultivars for use as rootstocks in Brazil (BOVÉ; AYRES, 2007; POMPEU JUNIOR, 2005; POMPEU JUNIOR; BLUMER, 2008).

Auler et al. (2008) found that 'Cleópatra' mandarin (C. reshni Hort. ex Tanaka) and 'Troyer' citrange (Poncirus trifoliate $\times C$. sinensis Osb.) were potential cultivars to substitute 'Rangpur' lime for 'Valência' orange canopy owing to good yield induction of these rootstocks compared with 'Rangpur' lime. In addition, the 'Troyer' citrange induced a low canopy with high productive efficiency, which can allow the increase of plant density by area. Other cultivars, such as 'Rough' lemon ( $C$. jambhiri Lush.) and 'C13' citrange $(C$. sinensis Osb. $\times$ P. trifoliate) also have the potential to substitute 'Rangpur' lime because of their resistance to diseases and good yield induction (STENZEL et al., 2003). 'C13' citrange also induces late fruit ripeness (POMPEU JUNIOR; BLUMER, 2014), which can be an advantage for the grower who can offer fruits to the market at different times, thus achieving better prices.

During citrus seedling growth, optimal conditions of shoot and root formation are desirable to guarantee that plants grow faster and 
are uniform to be used as high-quality rootstocks (SARMIENTO et al., 2016). Among the desired features of rootstocks, a well-developed root system plays an important role in soil exploratory capacity, anchorage, water and nutrient absorption, and potential associations with arbuscular mycorrhizal fungi (BACK et al., 2016; POMPEU JUNIOR, 2005). Optimum root systems lead to good shoot growth and development because they serve as the interface between the plant and the soil acquiring water and nutrients (SÁNCHEZ-BLANCO et al., 2014). Despite the overall importance of the root system for plant development and yield, root traits have rarely been investigated because of their size, depth, and difficulty of manipulation, thus requiring intensive labor to excavate and clean intact root systems on a large scale (RYAN et al., 2016).

An alternative to better explore root traits in plants is to use early detection techniques of potential root architecture. Computer models and specific software enable the identification of advantageous root characteristics (GONÇALVES; LYNCH, 2014; HAUCK et al., 2015). In addition to the advantage of faster characterization, image analysis software is an important tool that breeders can use to select plants with good root system architecture and increase the agronomic performance of plants (ZHU et al., 2011).

The plane image is used to capture and measure several parameters of root architecture and is strengthened by the fast development of low-cost cameras and scanners that can acquire digital images of high definition/resolution. Software programs are requisite tools for root researchers because they provide user-friendly procedures that make it feasible to rapidly capture datasets without significant mental fatigue (LE BOT et al., 2010).

Thereby, with the increase in demand for using alternative cultivars as rootstocks, initial shoot development and root system characterization is a potential technique to highlight early differences among cultivars that can allow the selection of better cultivars in a rapid manner. Thus, the aim of the present study was to evaluate the initial shoot development and root architecture of citrus rootstock cultivars.

\section{Materials and Methods}

\section{Rootstock cultivars}

Seeds from five citrus plants used as rootstocks were obtained from the Seeds Germplasm Bank of the Instituto Agronômico do Paraná, Brazil, on September 14, 2016, and stored in plastic bags at $10{ }^{\circ} \mathrm{C}$ for 10 days until experiment installation on September 24, 2016, to preserve the germination physiological potential. The common and scientific names and seed lot characteristics of each citrus rootstock are presented in Table 1.

Table 1. Common name, scientific name, date of harvest, germination (Germ.), 1000 seeds weight (1000 SW), and seed water content (WC) of the citrus rootstocks used in the study.

\begin{tabular}{lccccc}
\hline Common name & Scientific name & Harvest & Germ. (\%) & 1000 SW (g) & WC (\%) \\
\hline 'Cleopatra' Mandarin & C. reshni Hort. ex Tanaka & $06 / 27 / 2016$ & 40 & 102.79 & 30.46 \\
'Rangpur' lime & C. limonia Osb. & $05 / 14 / 2015$ & 88 & 62.26 & 28.01 \\
'Rough' lemon & C. jambhiri Lush. & $06 / 02 / 2016$ & 96 & 97.97 & 43.33 \\
'C13' citrange & C. sinensis Osb. $\times$ Poncirus trifoliate & $06 / 02 / 2016$ & 78 & 177.08 & 32.21 \\
'Troyer' citrange & P. trifoliate $\times$ C. sinensis Osb. & $06 / 02 / 2016$ & 79 & 237.16 & 33.74 \\
\hline
\end{tabular}


Seed sowing and seedling development

Initially, black polyethylene bags that had 51 holes drilled in the base and a $4.5 \mathrm{~L}$ capacity were filled with a mixture of sand and medium texture vermiculite in the ratio of $1: 1(\mathrm{v} / \mathrm{v})$. The substrate chemical and physical characteristics were $1.16 \mathrm{~kg}$ $\mathrm{L}^{-1}$ of bulk density, water retention capacity of 1.19 $\mathrm{mL} \mathrm{L}^{-1}, \mathrm{pH}$ of 7.46 , and electrical conductivity of $89.33 \mu \mathrm{S} \mathrm{cm}^{-1}$.

Before sowing, the seeds were kept for $24 \mathrm{~h}$ in an environment with $95 \%$ relative humidity and $22.5^{\circ} \mathrm{C}$ to standardize the initial water levels. The moisture content was determined by the oven method at $105^{\circ} \pm 3^{\circ} \mathrm{C}$ for $24 \mathrm{~h}$ using two replicates of ten seeds, following the methods described by the Rules for Seed Analysis (BRASIL, 2009) and the results were expressed in percentages. Three seeds previously treated with captan-based fungicide (Captan SC) were sown in each polyethylene bag at an effective depth 2-fold the seed size. After the sowing process, the bags were placed in a chapelshaped glass greenhouse, $5 \mathrm{~m}$ high and irrigated twice a day. The mean temperature was $31.6{ }^{\circ} \mathrm{C}$ during the evaluation period.

\section{Experiment design}

To characterize the citrus plants, a completely randomized block design with five replications was applied and the treatments were composed of five citrus rootstocks; each normal seedling was considered a plot in the present study. The normal seedling was selected based on the methodology applied in the plant nursery, retaining the most vigorous seedling that probably corresponded to the nucellar embryo, which is similar to the maternal plant (ANDRADE et al., 2007).

\section{Trait measurement}

At 30 and 45 days after emergence (DAE) of seedlings, shoots and roots were collected for analysis. For shoot analysis, the seedlings were cut at the substrate level and the data recorded for total number of leaves (counting expanded leaves), leaf area (by image analysis), diameter of the stem (caliper graduated in $\mathrm{mm}$ ), plant height (ruler graduated in $\mathrm{mm}$ ), fresh matter weight (mass measurement on balance), and dry matter weight (mass measurement on balance after shoot drying at $60{ }^{\circ} \mathrm{C}$ for 5 days).

For the root study, the black polyethylene bags containing the roots were placed horizontally under a sieve and the substrate was removed by washing, under constant water flow, to expose the roots without damage (GONÇALVES; LYNCH, 2014). The treatments were identified, and the roots were placed in black trays with water. With a digital photographic camera (Nikon D3100 with 18-55 mm lens, f/ 3.5, ISO 800, and 30 times optical zoom), photographs were taken in the presence of a scale. Subsequently, the images were analyzed in ImageJ software by the SmartRoot plugin (Figure 1) (LOBET et al., 2011). The program recorded root traits such as primary, secondary, and tertiary root numbers; root length; and root total volume. The percentage of secondary roots present in the upper third of the primary root were determined by counting. Fresh matter weight was analyzed by mass measurement on a balance and dry matter weight by mass measurement on a balance after shoot drying at $60{ }^{\circ} \mathrm{C}$ for 5 days. 
Figure 1. Image analyses in the ImageJ software using the SmartRoot plugin of roots from five rootstocks: A. 'C13' citrange; B. 'Troyer' citrange; C. 'Rough' lemon; D. 'Rangpur' lime; and E. 'Cleopatra' mandarin at 30 and 45 days after emergence $(\mathrm{DAE})$. Yellow color $=$ primary root; Green color $=$ secondary root; Blue color $=$ tertiary root.
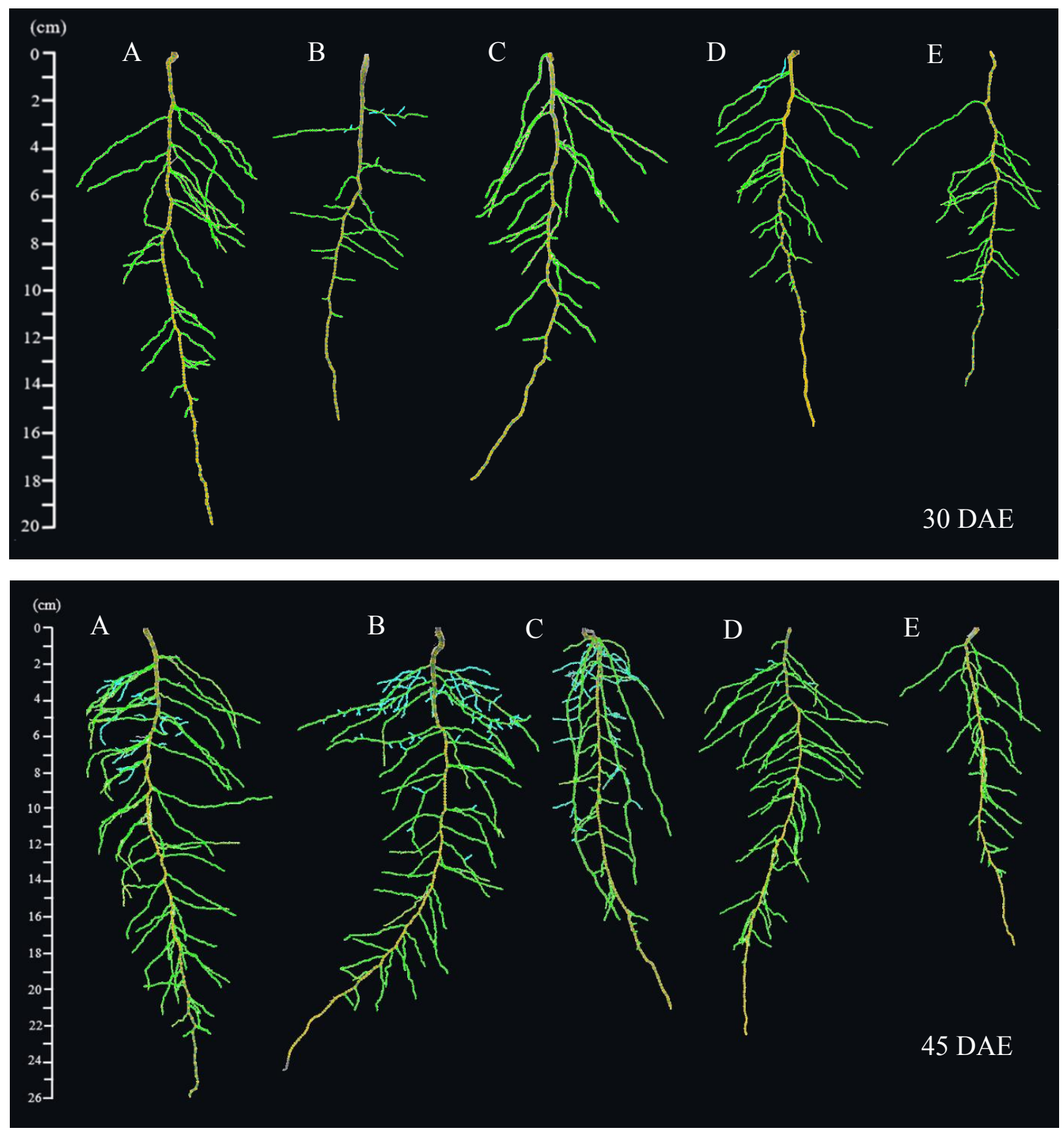

\section{Statistical analysis}

Shoot data (total number of leaves, leaf area, diameter of the stem, plant height, fresh matter weight, and dry matter weight) and root data of fresh and dry weights were submitted to analysis of variance (ANOVA) at 5\% of significance and the averages compared by Tukey's test $(5 \%)$. The remaining root data (primary, secondary, and tertiary root numbers and length; root total volume; and percentage of secondary roots in the upper third of the primary root) were standardized for variance 1 and studied by principal component analysis (PCA).

Statistical analyses for ANOVA and PCA were performed by $\mathrm{SAS}^{\circledR}$ University Edition using the procedures Proc glm and Proc princomp, respectively (SAS, 2014). 


\section{Results and Discussion}

\section{Shoot and root development}

In the first evaluation period (30 DAE), the ' $\mathrm{C} 13$ ' citrange differed from the other rootstocks in terms of higher shoot fresh and dry weights, followed by the 'Troyer' citrange. 'Rough' lemon and 'Rangpur' lime presented intermediary performance, not differing from 'Cleopatra' mandarin, which showed lower shoot fresh and dry weight. At 45 DAE, both citranges, 'C13' and 'Troyer' presented superior performance for shoot fresh and dry weights, and 'Cleopatra' mandarin continued to show the lowest performance, similar to 'Rough' lemon; 'Rangpur' lime had an intermediary performance (Figure 2).

Figure 2. Shoot fresh weight (SFW) and shoot dry weight (SDW) at 30 and 45 days after emergence (DAE) of five rootstocks: 'C13' citrange (CC); 'Troyer' citrange (TC); 'Rough' lemon (Ro.L.); 'Rangpur' lime (Ra.L.); and 'Cleopatra' mandarin (CM). Values followed by the same letter do not significantly differ between the treatments at $5 \%$ significance according to Tukey's test.

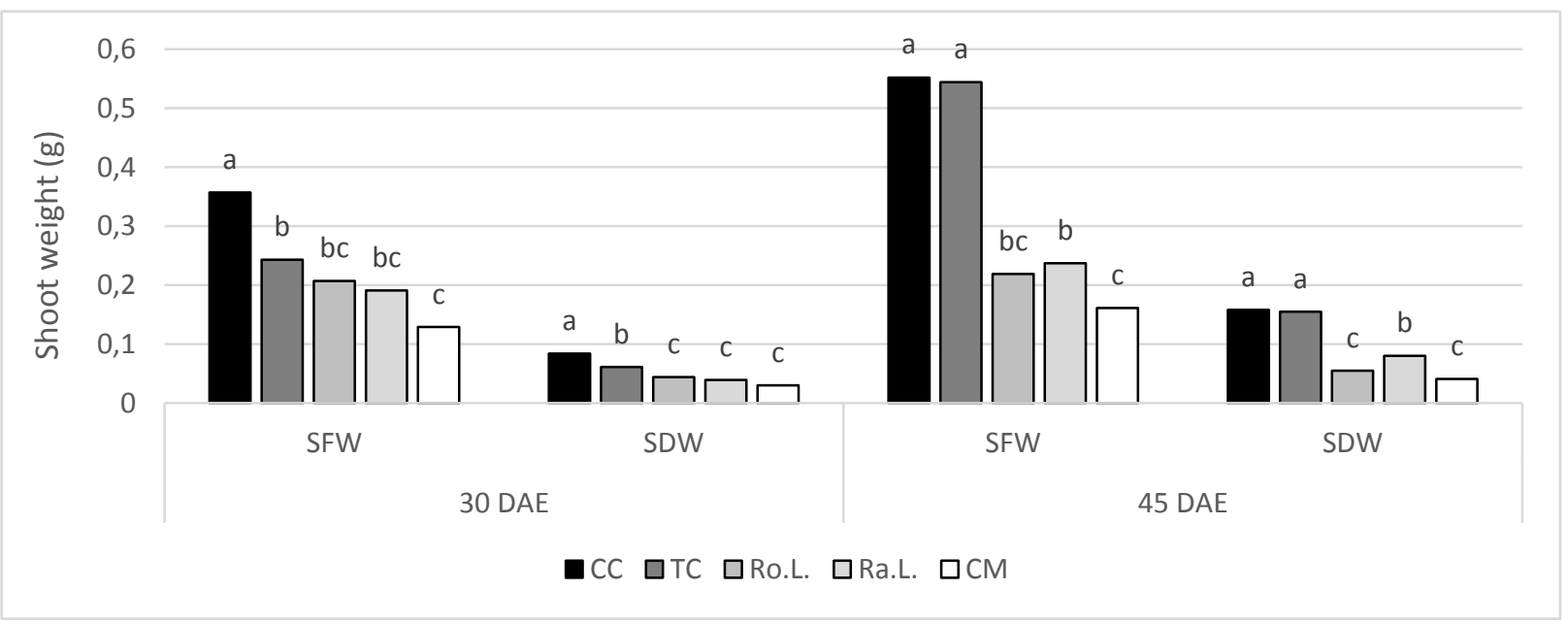

For root fresh weight 30 DAE, the 'C13' citrange and 'Rough' lemon rootstocks had higher performance that differed from the others. 'Troyer' citrange and 'Rangpur' lime presented intermediary performance, and did not differ from 'Cleopatra' mandarin, which showed lower root fresh weight. At 45 DAE, the 'C13' citrange and 'Troyer' citrange showed higher root fresh weight, differing from 'Cleopatra' mandarin and 'Rangpur' lime that showed lower performance (Figure 3).

Regarding root dry weight, the ' $\mathrm{C} 13$ ' citrange presented higher values followed by the 'Troyer' citrange and 'Rough' lemon at $30 \mathrm{DAE}$ and by 'Troyer' at 45 DAE. The 'Cleopatra' mandarin showed lower root dry weight on both evaluation periods, not differing from 'Rangpur' lime on 30
DAE and from 'Rangpur' lime and 'Rough' lemon on 45 DAE (Figure 3).

Concerning leaf area, the ' $\mathrm{C} 13$ ' citrange presented better performance on both evaluation periods, not differing from the 'Troyer' citrange at 45 DAE. In relation to shoot length, the ' $\mathrm{C} 13$ ' citrange at $30 \mathrm{DAE}$ showed better performance followed by the 'Troyer' citrange. On 45 DAE, both citranges differed from the other rootstocks with longer shoot lengths. For stem diameter, the citranges differed from the other cultivars with higher diameters at 30 DAE and the 'Troyer' citrange at 45 DAE showed better performance followed by the 'C13' citrange, which did not differ from the 'Rough' lemon and 'Cleopatra' mandarin (Figure 4). 
Figure 3. Root fresh weight (RFW) and root dry weight (RDW) at 30 and 45 days after emergence (DAE) of five rootstocks: 'C13' citrange (CC); 'Troyer' citrange (TC); 'Rough' lemon (Ro.L.); 'Rangpur' lime (Ra.L.) and 'Cleopatra' mandarin (CM). Values followed by the same letter do not significantly differ between the treatments at $5 \%$ significance according to Tukey's test.

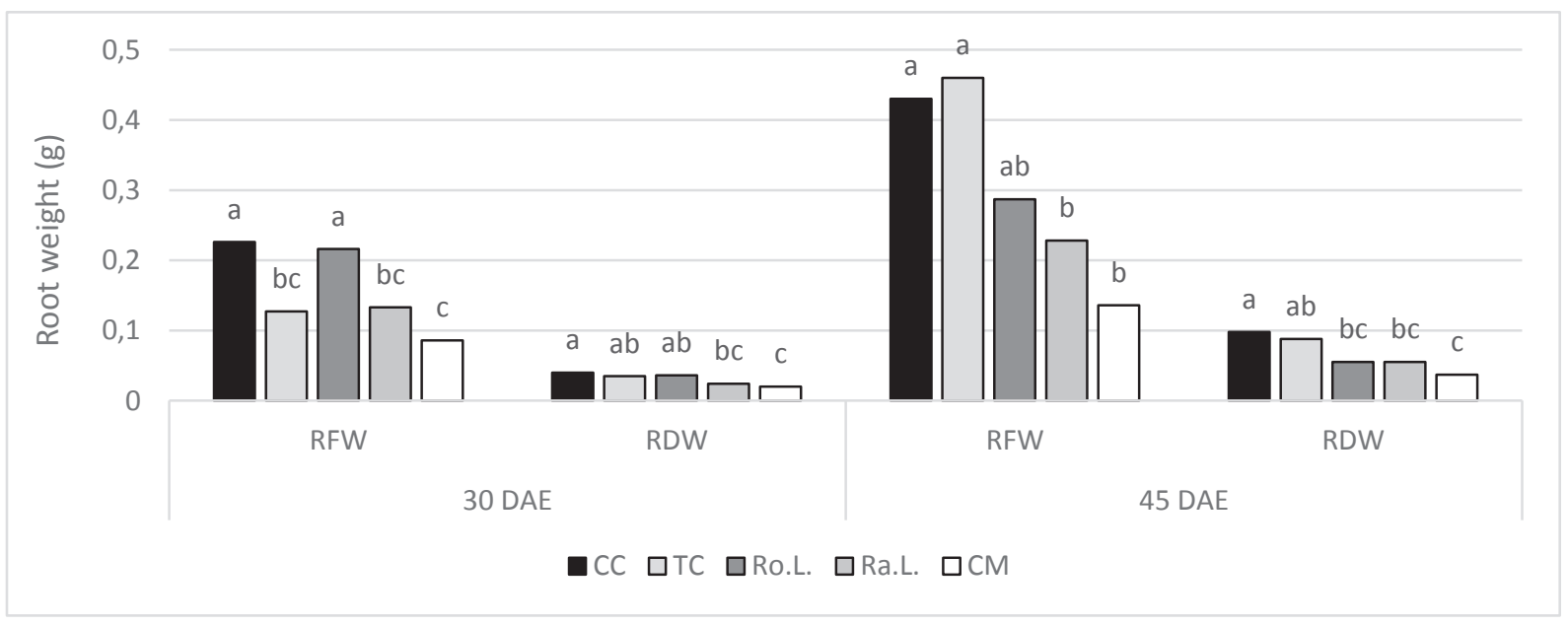

Figure 4. A. Leaf area $\left(\mathrm{cm}^{2}\right)$, B. shoot length $(\mathrm{cm})$, and C. stem diameter $(\mathrm{mm})$ at 30 and 45 days after emergence (DAE) of five rootstocks: 'C13' citrange (CC); 'Troyer' citrange (TC); 'Rough' lemon (Ro.L.); 'Rangpur' lime (Ra.L.); and 'Cleopatra' mandarin (CM). Values followed by the same letter do not significantly differ between the treatments at $5 \%$ significance according to Tukey's test.
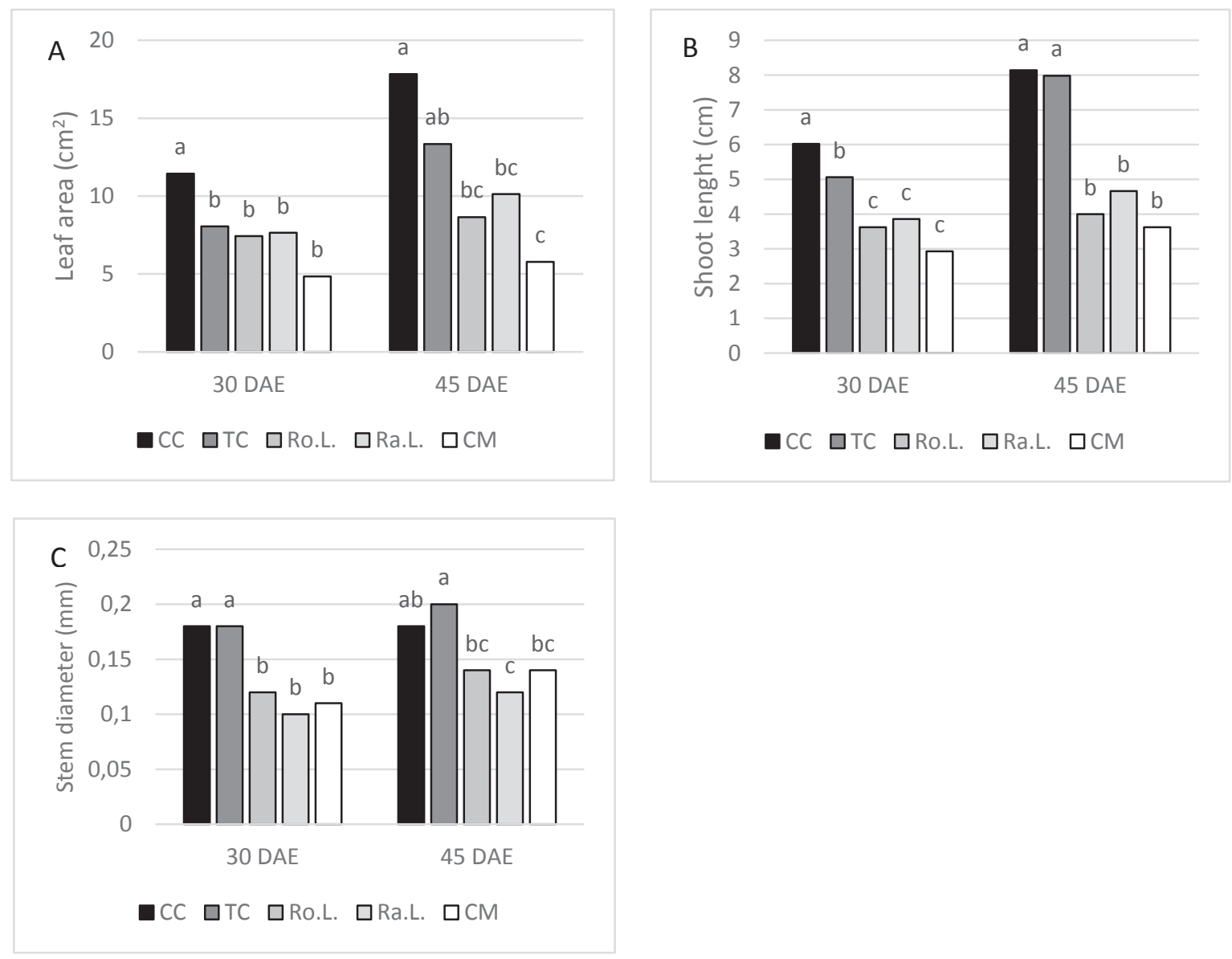
Transpiration and photosynthesis of a plant and its microclimate characteristics essentially depend on the absorbed solar radiation, which is conditioned by leaf area and its efficiency of interception of radiant energy. The reduction in the canopy leaf area determines an exponential decrease of solar radiation interception efficiency and, consequently, reduction of the photosynthesis process and dry mass accumulation (PILAU; ANGELOCCI, 2015). This correlation is in accordance with the results found in the present study, in which the ' $\mathrm{C} 13$ ' citrange cultivar had the largest leaf area on both evaluation periods, followed by the 'Troyer' citrange at $45 \mathrm{DAE}$, and had the largest shoot and root dry mass accumulation and shoot development.
This would result in an earlier rootstock formation, which is desirable to the citrus seedling production.

\section{Root architecture}

The PCA showed that the two principal components were responsible for $80.40 \%$ of the total variation, in which Principal Component 1 $\left(\mathrm{PC}_{1}\right)$ represented 56.5\% and Principal Component $2\left(\mathrm{PC}_{2}\right)$ represented $24.0 \%$. The first and second new components $\left(\mathrm{PC}_{1}\right.$ and $\mathrm{PC}_{2}$, respectively) represented a linear combination of the parameters standardized (STD) with different loadings as shown by Equations 1 and 2:

$$
\begin{aligned}
& P C 1=0.44 \times\left(P R L_{S T D}\right)+0.41 \times\left(\mathrm{SRL}_{\mathrm{STD}}\right)+0.35 \times\left(\mathrm{TRL}_{\mathrm{STD}}\right)+0.38 \times\left(N S R_{S T D}\right)+0.37 \times \\
& \left(N T R_{S T D}\right)+0.15 \times\left(P E R C_{S T D}\right)-0.19 \times\left(A N G L E_{S T D}\right)+0.42 \times\left(R V_{S T D}\right) \\
& P C 2=-0.15 \times\left(P R L_{S T D}\right)+0.02 \times\left(\mathrm{SRL}_{\mathrm{STD}}\right)+0.35 \times\left(\mathrm{TRL}_{\mathrm{STD}}\right)-0.30 \times\left(N S R_{S T D}\right)+0.33 \times \\
& \left(N T R_{S T D}\right)-0.46 \times\left(P E R C_{S T D}\right)+0.61 \times\left(A N G L E_{S T D}\right)+0.25 \times\left(R V_{S T D}\right)
\end{aligned}
$$

The new component $\mathrm{PC}_{1}$ discriminated citrus rootstocks by primary root length (PRL loading = 0.44 ), secondary root length (SRL loading $=0.41$ ), and root volume (RV loading $=0.42$ ), whereas $\mathrm{PC}_{2}$ discriminated citrus rootstock by root insertion angle (ANGLE loading $=0.61)$ and percentage of roots in the upper third (PERC loading $=-0.46)$ (Figure 5).

For $\mathrm{PC}_{1}$ (Equation 1), two groups based on assay periods were identified and the citrus rootstocks evaluated at 30 DAE showed negative values for $\mathrm{PC}_{1}$; however, they were clustered in the same group. The analysis at $45 \mathrm{DAE}$ demonstrated that the 'Troyer' citrange, 'C13'citrange, 'Rangpur' lime, and 'Rough' lemon had the higher positive value for $\mathrm{PC}_{1}$, whereas 'Cleopatra' mandarin had a negative value clustering at $30 \mathrm{DAE}$ (Figure 5). This result demonstrated that the 'Cleopatra' mandarin had a smaller primary root, secondary root, and volume than the other cultivars evaluated at the same time. This underperformance can be attributed to the delay in emergence, which is characterized by being slow and uneven on this cultivar (POMPEU JUNIOR, 2005; POMPEU JUNIOR; BLUMER 2014). This also leads to a delay in root development and because the primary root, secondary root, and root volume are variables that provide soil-based resources to give support and stability to the upright structure of the plant and for the storage of carbohydrates and other reserves (RYAN et al., 2016; ZHU et al., 2011), this cultivar will present a delay in rootstock formation. Moreover, several authors have reported that the scion on 'Cleopatra' mandarin rootstocks also presents a delay in the beginning of production (POMPEU JUNIOR, 2005; POMPEU JUNIOR; BLUMER 2014). 
Figure 5. Root insertion angle (ANGLE); root volume (RV); primary root length (PRL); secondary root length (SRL); tertiary root length (TRL); number of secondary root (NSR); number of tertiary root (NTR), and percentage of roots in the upper third (PERC) at 30 and 45 days after emergence (DAE) of five rootstocks: 'C13' citrange (C13 C.); 'Troyer' citrange (Troyer C.); 'Rough' lemon (Rough L.); 'Rangpur' lime (Rangpur L.); and 'Cleopatra' mandarin (Cleopatra M.).
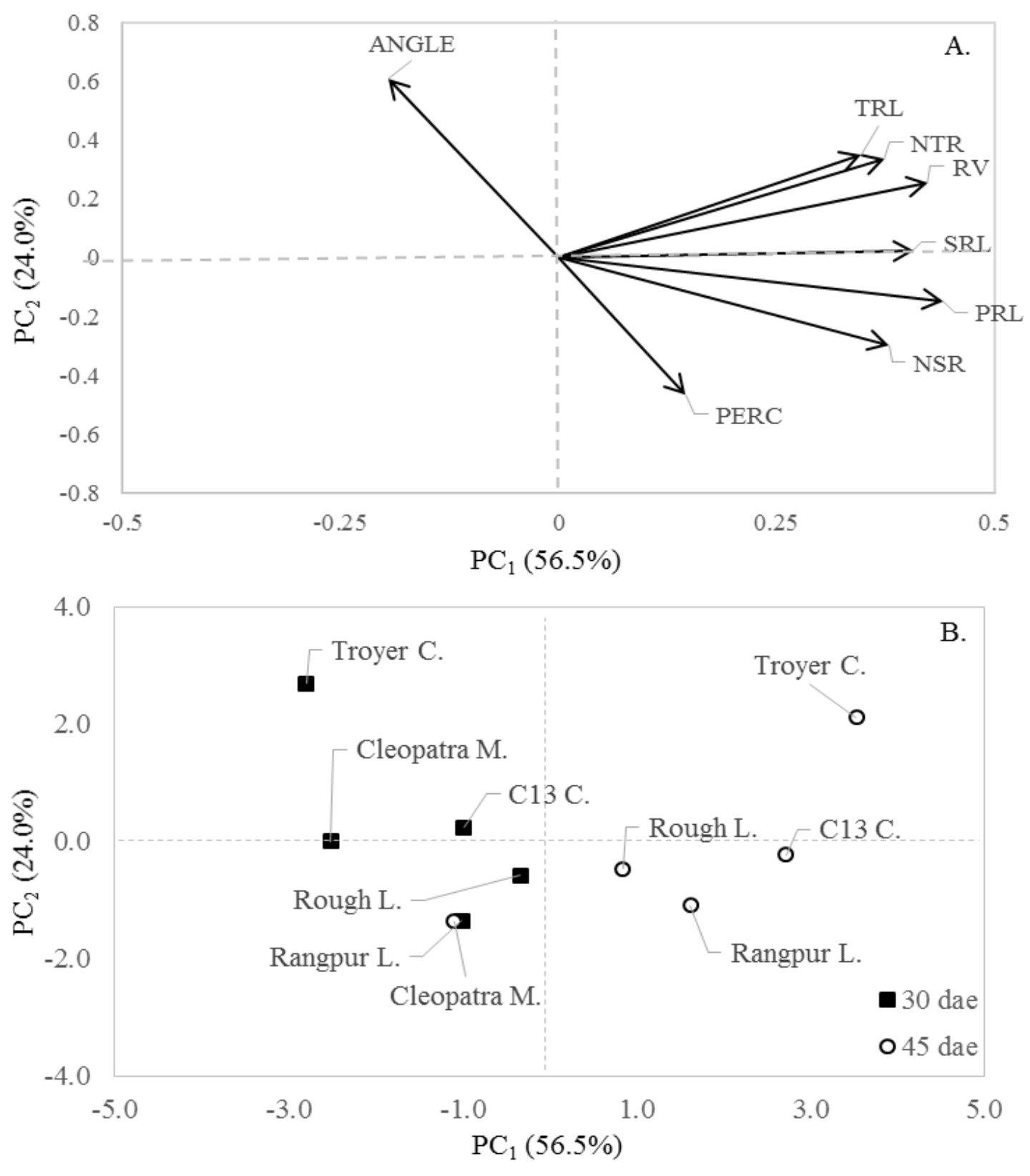

However, with more time this cultivar can reach higher root development, as found by Dalal and Thakur (2011) in a 17-year-old pineapple orange trees grown on 'Cleopatra' mandarin, where this rootstock presented extensive lateral root system development, mostly in the upper layer $0-15 \mathrm{~cm}$ depth, and a dense and large canopy. A similar result was found by Neves et al. (2008) who evaluated 12-year-old 'Ponkan' mandarin (C. reticulata Blanco) orchard and found that 'Cleopatra' mandarin had higher root length in the planting row $(16.56 \mathrm{~m})$ compared to 'Rangpur' lime (6.00 m), 'Rough' lime $(5.70 \mathrm{~m})$, and ' $\mathrm{C} 13$ ' citrange $(4.49 \mathrm{~m})$. 
$\mathrm{PC}_{2}$ (Equation 2) showed more positive values than the other citrus rootstocks at $30 \mathrm{DAE}$ for 'Troyer' and 'C13' citranges, and at 45 DAE for 'Troyer' citrange. As described previously, this new component discriminates based on the root insertion angle (ANGLE loading $=0.61$ ) and percentage of roots in the upper third (PERC loading $=-0.46$ ). Both citranges at $30 \mathrm{DAE}$ and the 'Troyer' citrange at $45 \mathrm{DAE}$ presented fewer roots in the upper third of the primary root and a higher insertion angle, indicating that these plants can explore the soil at depth and more horizontally than others. Similar behavior was observed by Dalal and Thakur (2011) in the field, where the 'Troyer' citrange had an intensive lateral root development growing at depth, and presented a significant number of roots up to 60 $\mathrm{cm}$ depth and close to the trunk $(0-75 \mathrm{~cm})$. Owing to its root system architecture, the 'Troyer' citrange has the potential to increase plant density by area; the depth and short root system will demand less spacing and decrease competition between plants. Furthermore, this cultivar produces a lower canopy, with high productivity efficiency in relation to its volume, which is a characteristic that allows good levels of yield with an increase of plant density by area (AULER et al. 2008).

Overall, 'Rangpur' lime presented inferior performance compared to the other citranges in the present study. Therefore, 'Troyer' and 'C13' citranges could be good alternatives as substitutes for the 'Rangpur' lime rootstock for citrus cultivation. Their characteristics of seedling formation, resulting in an early rootstock formation and their root architecture, exploring the soil in depth and more horizontally than others, enables them to increase plant density by area. Moreover, 'Trifoliate' orange rootstock and its hybrids, as the citranges, have great potential to reduce the canopy tree size (POMPEU JUNIOR, 2005), which allows an increase in the number of trees per unit of area, leading to a fast return to the grower on the investment to establish the orchard (TAZIMA et al., 2014).
Ryan et al. (2016) claimed that the shape and function of roots of plants grown in the field could be quite distinct from those of roots of plants grown in pots owing to the physical, chemical, and biological complexity of the soil, and environmental conditions, including water and nutrient availability. However, the capacity of the plant to adapt to the environment will also be influenced by its genetic characteristics, as can be seen in the present study, where even being irrigated twice a day the citrange roots spread deep into the soil. Neves et al. (2010) studied citrus cultivation in different plantation systems (tillage and conventional) and found that the amount of roots and the effective depth of the root system were not influenced by the different systems. The citrus root system overcame the differences imposed by the plantation system, in which the soil from the conventional plantation presented greater resistance to inter-row penetration compared to the zero-tillage system.

\section{Conclusions}

- 'C13' and 'Troyer' citranges showed good shoot development during the evaluation period.

- 'Cleopatra' mandarin showed smaller shoot and root development during both evaluation periods.

- 'Troyer' citrange presented fewer roots in the upper third of the primary root and a higher angle, with the roots growing at a greater depth and more horizontally than others.

\section{Acknowledgments}

The authors would like to thank the Coordination for the Improvement of Higher Education Personnel (CAPES) and the National Research Council (CNPq) for the financial support of this work. 


\section{References}

ALMEIDA, C. O.; PASSOS, O. S. Citricultura brasileira: em busca de novos rumos desafios e oportunidades na região Nordeste. Cruz das Almas: Embrapa Mandioca e Fruticultura, 2011. $160 \mathrm{p}$.

ANDRADE, R. A.; MARTINS, A. B. G.; LEMOS, E. G. M.; LUZ, F. J. F.; SILVA, M. T. H. Detecção de polimorfismo em porta-enxertos para citros. Revista Brasileira de Fruticultura, Jaboticabal, v. 29, n. 2, p. 345349, 2007. DOI: 10.1590/S0100-29452007000200030.

AULER, P. A. M.; FIORI-TUTIDA, A. C. G.; TAZIMA, Z. H. Comportamento da laranjeira 'Valência' sobre seis porta-enxertos no noroeste do paraná. Revista Brasileira de Fruticultura, Jaboticabal, v. 30, n. 1, p. 229-234, 2008. DOI: $10.1590 / \mathrm{S} 0100-29452008000100042$.

AULER, P. A. M.; LEITE JUNIOR, R. P.; TAZIMA, Z. H.; ANDRADE, P. F. S. A citricultura no Paraná. Citricultura Atual, Cordeirópolis, v. 1, n. 99, p. 17-20, 2014.

BACK, M. M.; ALTMANN, T.; SOUZA, P. V. D. Influence of arbuscular mycorrhizal fungi on the vegetative development of citrus rootstocks. Pesquisa Agropecuária Tropical, Goiânia, v. 46, n. 4, p. 407-412, 2016. DOI: $10.1590 / 1983-40632016 v 4642180$.

BENJAMIN, G.; TIETEL, Z.; PORAT, R. Effects of rootstock/scion combinations on the flavor of citrus fruit. Journal of Agriculture and Food Chemistry, Washington, v. 61 , n. 47 , p. 11286-11294, 2013. DOI: 10.1021/ jf402892p.

BOVÉ, J. M.; AYRES, A. J. Etiology of three recent diseases of citrus in São Paulo State: sudden death variegated chlorosis and Huanglongbing. IUBMB Life, Oxford, v. 59, n. 4, p. 346-354, 2007. DOI: 10.1080/15216540701299326.

BRASIL. Ministério da Agricultura e da Reforma Agrária. Regras para análise de sementes. Brasília, DF: SNDA/DNDV/CLAV, 2009. 398 p.

DALAL, R. P. S.; THAKUR, A. Fibrous root distribution in pineapple orange trees under semi-arid irrigated ecosystem. Advances in Horticultural Science, Florence, v. 25 , n. 1, p. 32-36, 2011. DOI: 10.13128/ahs-12782.

FOOD AGRICULTURAL ORGANIZATION - FAO. Production - crops. Roma: FAO, 2015. Disponível em: http://faostat3.fao.org/compare/E. Acesso em: $02 \mathrm{dez}$. 2016.

GONÇALVES, S. L.; LYNCH, J. P. Raízes de plantas anuais: tolerância a estresses ambientais, eficiência na absorção de nutrientes e métodos para seleção de genótipos. Londrina: EMBRAPA, 2014. 67 p.
HAUCK, A. L.; NOVAIS, J.; GRIFT, T. E.; BOHN, M. $\mathrm{O}$. Characterization of mature maize (Zea mays L.) root system architecture and complexity in a diverse set of ExPVP inbreds and hybrids. Springerplus, Heidelberg, v. 4, p. 424-445, 2015. DOI: 10.1186/s40064-015-1187-0.

LE BOT, J.; SERRA, V.; FABRE, J.; DRAYE, X.; ADAMOWICZ, S.; PAGÈS, L. DART : a software to analyse root system architecture and development from captured images. Plant and Soil, Netherlands, v. 326, n. 2, p. 261-273, 2010. DOI: 10.1007/s11104-009-0005-2.

LOBET, G.; LOIC, P.; DRAYE, X. A novel imageanalysis toolbox enabling quantitative analysis of root system architecture. Plant Physiology, Rockville, v. 157, n. 1, p. 29-39, 2011. DOI: 10.1104/pp.111.179895.

MEDINA, C. L.; RENA, A. B.; SIQUEIRA, D. L.; MACHADO, E. C. Fisiologia dos citros. In: MATTOS JUNIOR, D. M.; NEGRI, J. D.; PIO, R. M.; POMPEU JUNIOR, J. (Ed.). Citros. Campinas: Instituto Agronômico e Fapesp, 2005. p. 39-57.

MOURÃO FILHO, F. A. A.; ESPINOZA-NÚÑEZ, E.; STUCHI, E. S.; ORTEGA, E. M. M. Plant growth, yield, and fruit quality of 'Fallglo' and 'Sunburst' mandarins on four rootstocks. Scientia Horticulturae, Amsterdam, v. 114, n. 1, p. 45-49, 2007. DOI: 10.1016/j. scienta.2007.05.007.

NEVES, C. S. V. J.; STENZEL, N. M. C.; CARVALHO, S. L. C.; FURLANETO, T. L. R.; OKUMOTO, S. H. Sistema radicular de quatro porta enxertos sob copa de tangerina 'Poncã'. Ciência e Agrotecnologia, Lavras, v. 32 , n. 2 , p. $487-492$, 2008. DOI: $10.1590 /$ S141370542008000200022 .

NEVES, C. S. V. J.; TAVARES FILHO, J.; BRITO, O. R.; YAMASHITA, F.; TORMEM, V.; FONSECA, I. C. B. Huerto de cítricos plantado con sistema de cero labranza y sistema convencional. Semina: Ciências Agrárias, Londrina, v. 31, n. 1, p. 1263-1274, 2010. DOI: 10.5433/1679-0359.2010v31n4Sup1p1263.

PILAU, F. G.; ANGELOCCI, L. R. Leaf area and solar radiation interception by orange tree top. Bragantia, Campinas, v. 74, n. 4, p. 476-482, 2015. DOI: $10.1590 / 1678-4499.0130$.

POMPEU JUNIOR, J.; BLUMER, S. Morte súbita dos citros: suscetibilidade de seleções de limão-cravo e uso de interenxertos. Revista Brasileira de Fruticultura, Jaboticabal, v. 30, n. 4, p. 1159-1161, 2008. DOI: 10.1590/S0100-29452008000400052.

POMPEU JUNIOR, J.; BLUMER, S. Híbridos de trifoliata como porta-enxertos para laranjeira Pêra. Pesquisa Agropecuária Tropical, Goiânia, v. 44, n. 1, p. 9-14, 2014. DOI: 10.1590/S1983-40632014000100007. 
POMPEU JUNIOR, J. Porta-enxertos. In: MATTOS JUNIOR, D. M.; NEGRI, J. D.; PIO, R. M.; POMPEU JUNIOR, J. (Ed.). Citros. Campinas: Instituto Agronômico e Fapesp, 2005. p. 63-94.

RYAN,P.R.;DELHAIZE,E.;WATT,M.;RICHARDSON, A. E. Plant roots: understanding structure and function in an ocean of complexity. Annals of Botany, Oxford, v. 118, n. 4, p. 555-559, 2016. DOI: 10.1093/aob/mcw192.

SÁNCHEZ-BLANCO, M.; ÁlVAREZ, S.; ORTUÑO, M. F.; RUIZ-SÁNCHEZ, M. C. Root system response to drought and salinity: root distribution and water transport. In: SÁNCHEZ-BLANCO, M.; ÁlVAREZ, S.; ORTUÑO, M. F.; RUIZ-SÁNCHEZ, M. C. Root Engineering: basic and applied concepts. New York: Springer-Verlag, 2014. p 325-352. DOI: 10.1007/978-3642-54276-3_15.

SARMIENTO, A.I.P; GIULIANI J.C.; SOUZA, P.V.D. Morfologa de frutos e sementes de porta-enxertos de citros cultivados em ambiente protegido. Revista U.D.C.A Actualidad \& Divulgación Científica, Cartagena, v. 19, n. 1, p. 17-24, 2016. DOI: 10.31910/rudca.v19.n1.2016.106.
STATISTICAL ANALYSIS SYSTEM - SAS. SAS巴

University Edition. Cary: SAS Institute Inc., 2014.

STENZEL, N. M. C.; NEVES, C. S. V. J.; GOMES, J. C.; MEDINA, C. C. Performance of ponkan mandarin on seven rootstocks. Hortscience, Alexandria, v. 38, n. 2, p. 176-178, 2003. DOI: 10.21273/HORTSCI.38.2.176.

TAZIMA, Z. H.; NEVES, C. S. V. J.; YADA, I. F. U.; LEITE JÚNIOR, R. P. Performance of 'Okitsu' satsuma mandarin trees on different rootstocks in Northwestern Paraná State. Semina: Ciências Agrárias, Londrina, v. 35, n. 5, p. 2297-2308, 2014. DOI: 10.5433/1679-0359.2014v35n5p2297.

ZHU, J.; INGRAM, P. A; BENFEY, P. N.; ELICH, T. From lab to field, new approaches to phenotyping root system architecture. Current Opinion in Plant Biology, London, v. 14, n. 3, p. 310-317, 2011. DOI: 10.1016/j. pbi.2011.03.020. 